Erdem, ì. (2013). Konuşma dili açısından Arapça ve Farsça alıntı kelimelerin bugünkü durumu. Ana Dili Eğitimi Dergisi, 1(1), 92-100.

Ana Dili Eğitimi Dergisi
Journal of Mother Tongue Education
ADED - JOMTE
www.anadiliegitimi.com

\title{
Konuşma Dili Açısından Arapça ve Farsça Alıntı Kelimelerin Bugünkü Durumu
}

\author{
ilhan Erdem*
}

\section{Özet}

Tarihi süreç içerisinde Farsça ve Arapçadan pek çok kelime Türkçeye girmiştir. Yıllarca kullanılan bu kelimeler artık yazılış ve söyleyişiyle Türkçeye mal olmuştur. Alıntı kelimeler; bünyesindeki seslerin düşme, türeme, değişme gibi birtakım ses olaylarına maruz kalarak Türkçe söyleyişe uygun hâle gelmiştir. Bazen de o dile özgü yapılarını sürdürmüştür. Mesela Türkçede alıntı kelimelerde uzun söyleyişler yaygındır. Bu ve benzeri bazı sorunlar konuşma dili açısından incelenmelidir. Standart konuşma dili bu incelemelere göre oluşturulmalıdır. Çalışmamız da bu sorunlara cevap vermek amacıyla hazırlanmıştır. Alıntı kelimeler; fonetik ve morfolojik özellikleri esas alınarak sınıflandırılmış ve konuşma dili açısından özellikleri belirtilmiştir.

Anahtar Kelimeler: Konuşma dili, alıntı kelimeler, Arapça ve Farş̧a

\section{Current Status of Arabic and Persian Loan Words from the Point of Spoken Language}

\begin{abstract}
Many words of Persian and Arabic origin have entered Turkish in historical period. Later, those words transformed into Turkish from the points of spelling and pronunciation. The loan words became Turkish via alteration of voices like prothesis, loss or assimilation. But, words could preserve their basic structure in the original language. For example, there is no long vowel in Turkish. However there are long vowels in some loan words. Such problems should be academically investigated from the points of spoken language. Hence, standard spoken language should be composed according to the results of the investigation. The present study was made to contribute to the solution of the stated problem. The loan words were classified by taking their phonetical and morphological properties into account. Additionally, the properties of loan words used in spoken language were determined.
\end{abstract}

Key words: Spoken language, loan words, Arabic and Persian.

\section{Giriş}

Bir iletişim vasıtası olan dil, bireyler arasında olduğu gibi toplumlar arası ilişkilerde de önemli bir işleve sahiptir. Dil aynı zamanda kültür aktarımı olduğundan toplumlar arası ilişkiler bir bakıma diller ve kültürler arası ilişkiler demektir.

Toplumların dil özellikleri incelendiğinde, çeşitli nedenlerle dilden dile karşııklı kavram ve söz aktarımlarının olduğu görülmektedir. Anadolu ve Rumeli coğrafyasında kurulup gelişmiş olan Oğuzca temelindeki Türkiye Türkçesi, bu yönden ilgi çekici bir özellik taşır. Türkiye Türkçesi, tarihi boyunca bir yandan Arapça ve Farsça gibi doğu dillerinin yanında Yunanca, İtalyanca, Slavca, Rumence, Macarca, Fransızca, Almanca, İngilizce gibi batı dillerinin etkisinde kalmıştır (Korkmaz, 2003).

Türklerin İslam medeniyeti alanına girmesi ile birlikte, Türkçenin Arap ve Fars dilleri ile olan ilişkileri kısa sürede hayli yoğunlaşmıştır. Dolayısıyla din ve ilim dili olan Arapça ile edebiyat dili olan Farsça Türkçeyi büyük oranda etkilemiştir. Bu etkileşme, XV. yüzyıl ortalarından başlayarak 1839

${ }^{*} Y r d$. Doç. Dr., İnönü Üniversitesi Eğitim Fakültesi. Türkçe Eğitimi Bölümü. Malatya.

E-posta: ilhan.erdem@inonu.edu.tr 
Tanzimat dönemine kadar sürmüştür (Korkmaz, 2003). Aynı medeniyet dairesinde olmaları hasebiyle Türkçeden de bu dillere pek çok kelime geçmiştir (bk. Akçay, 2001; Aytaç:1994)

Yüzlerce yıldan beri işlenerek gelişmesini devam ettirmiş olan Türkçe, kendi bünyesindeki değişiklikler sonucu birçok yeni değeri kelime servetine katmıştır. Kelimelerle birlikte yabancı dillerin etkisiyle Türkçeye girmiş biçimler de çoktur. Dilimizdeki bu yabancı ögeler, dil bilgisinin dayandığı temel değerleri değiştirememiş, kelime varlığını zenginleştiren birer alıntı olarak kalmışlardır. Bu unsurlar, hiçbir zaman cümle kurgusundaki örgüyü bozamamıştır (Usta, 1990)

Sakaoğlu (2005), diller arası etkileşimleri güzel bir benzetmeyle apartman komşuluğuna benzetmiştir. Türkler, ülke komşularımızdan kolaylıkla kelime hatta kural almayı hemen benimsemişlerdir. Sanki bir apartmanda oturuyoruz da üst katımıza veya karşımıza birileri taşınmış çocuklarımız da hemencecik çocuklarıyla kaynaşmışır. Türkler, çok değişik dillerden kelime almıştır. Sayıları on binleri bulan bu kelimeleri bize benzetivermişiz. Yani yabancı kelimeleri bizim kelimelerimizin özellikleriyle süsleyivermişiz. Farisilerin divar dedikleri kelimeyi biz duvar olarak kullanmaktayız.

Başka dillerden Türkçeye girmiş kelimelerin telaffuzlarında zaman içinde fonetik değişmeler meydana gelerek bu kelimeler Türkçeleşmişlerdir. Bu ameliye birkaç türlü gerçekleşmiştir (Duman, 2004) Türkçede karşılığı bulunmayan sesler, Türkçedeki özellikleri bakımından kendisine yakın seslerle karşılanmışlardır. Mesela; Arapçanın zel, ze, zı, zad seslerini Türkçede bir tek z sesiyle; peltek se, sin, sad harflerinin karşıladıkları sesleri de yine tek bir s sesiyle karşılamak gibi.

Alıntı kelimeler; bünyesindeki seslerin düşme, türeme, değişme gibi birtakım ses olaylarına maruz kalarak Türkçe söyleyişe uygun hâle gelmişlerdir. Minare < menâre, tezgâh < destgâh, akıl < akl, istasyon < station vb. Pek çok kelime anlamca değişikliklerin yanında ses özellikleri bakımından da Türkçeleşme süreçlerini tamamlamışlardır.

Arapça ve Farsça kökenli kelimelerde bulunan ses özelliklerini korumak, Türkçenin doğru telaffuz edilmesiyle doğrudan ilgilidir. Söz konusu sesleri ve söyleyişleri korumak, kişisel olmayıp toplumsaldır. Bu şekilleri korumak anlama açıklık getirmek için gerekli olup gramer kaideleri de bunu böyle gerektirmektedir. Vakıf ile vâkıf ve kanun ile kânun arasındaki ses farkını korumak anlam açısından da önemlidir (Zülfikar, 2002a).

Kelimelerin anlam kazanmasında kullanıldıkları dilin özelliklerinin göz önünde bulundurulması gerekir. Alıntı kelimelerde kelimelerin asıl dildeki fonksiyonları göz ardı edilirse kullanılan dilde de anlam karışıklıkları kaçınılmazdır. Örneğin katil zanlısı kelime grubundaki katilin a'sını uzun söylediğimizde anlam tamamen değişmektedir. Kâtil katletme işini yapmış ve bu durum kanıtlanmıştır. Oysa katil zanlısı kelime grubunda bir zan vardır ve zannın olduğu yerde de bir kesinlik değil şüphe egemendir. Mütehassıs- mütehassis, mütevazi-mütevazı, kanun-kânun, varis-vâris, vakıfvâkıf vb. pek çok kelimede aynı anlam karışıklığı mevcuttur.

Faili meçhul kelime grubunda da yanlış olarak tamlamalı bir kullanım vardır. Tamlamalı söyleyiş anlamı bozarken aynı zamanda da telaffuz farklııı̆ını gündeme getirmektedir. Bilindiği gibi Farsça tamlamalar anlamlandırılırken son kelimeden çözümlenmeye başlanır. Fail-i meçhul tamlamasının anlamı bilinmeyen faildir. Hâlbuki bu kullanımdan kastedilen failin bilinmemesidir. Ayrıca tamlamalı söyleyişte vurgu ilk hecesindeyken faili şeklinde iyelik eki almış halinde vurgu iyelik ekindedir. Çünkü iyelik ekleri vurgulu (Zülfikar, 2002b) söylenmelidir.

Arapça ve Farsçadan alıntı kelimelerin telaffuz özellikleri belirlenirken bazı dilciler, bu dillerin ses özelliklerinin korunmaya çalışıldığı suçlamasında bulunmaktadırlar. Hâlbuki bu sözler, birer yabancı söz olmaktan çıkarak dilin ses ve şekil yapısına uydurularak Türkçeleşmiş, yazı ve konuşma diline mal olmuş sözlerdir. Bunlar artık dilin malı olduğu için Türkçe yapım ekleri ve yardımcı fiiller ile genişletilerek yeni yeni söz ve kavramlar da yaratmış, dili işletmiştir (Korkmaz, 2003; Zülfikar.2002a).

Bir dile giren alıntı kelimelerde geldikleri dilden ayrılan fonetik özellikler bulunabilir. Bu durumda dil almış olduğu kelimeleri kendi fonetik yapısına uydurma veya yaklaştırma çabası içine 
girer. Bu nedenlerden ötürü alıntı kelimelerde az veya çok ses değişiklikleri veya ses olayları meydana gelir. Bu tür değişikliklerin bir kısmının örnekseme yoluyla, bir kısmının galat olarak ortaya çıkmış olduğunu görürüz (Özçelik 2002). Son zamanlarda özellikle İngilizcenin etkisiyle Arapça tamlamalı isimler yanlış yazılmakta ve söylenmektedir. Osmanlı Türkçesinde el takısı almış isimlerin söylenişinde bir standart oluşmasına karşın özenti kaynaklı söyleyişler özelikle medyada daha çok revaçta olup yanlış yazılmakta ve söylenmektedir.

Günümüzde diksiyonlarıyla mesleklerini icra eden pek çok kişinin Arapça ve Farsçadan dilimize girmiş kelimeleri yanlış telaffuz ettikleri görülmektedir. Bunların düzeltilmesi için de bahsi geçen dillerden Türkçemize geçen kelimelerin dilimizde aldıkları şekilleri bilmek gerekir. Arapça ve Farsçadan dilimize girmiş bu kelimelerin bakiyeleri Osmanlı Türkçesidir. Arapça ve Farsçanın etkisi bu derece kalıcı ve yoğun olduğuna göre, iyi bir diksiyona sahip olmak için Osmanlı Türkçesiyle ilgili bir eğitim almak şarttır. Kabul etmek gerekir ki Osmanlı Türkçesindeki Arapça ve Farsça kelimeler, Türkçemizi derinden etkilemiştir. Dilimize bu dillerden geçmiş sayısız kelime mevcuttur. Bu kelimelerin telaffuzunda farklııkların olması gayet doğaldır. Çünkü uzun ünlü gibi Türkçede olmayan bazı söyleyiş özellikleri bu dillerden dilimize girmiş bulunmaktadır.

Sorun sadece telaffuzla sınırlı kalmayıp yazmada da pek çok yanlışın yapılmasının sebebi, alıntı kelimelerin özelliklerinin bilinmemesidir. Ünsüz yumuşaması, ünsüz benzeşmesi, ünlü düşmesi, ünsüz türemesi, ünlü uyumları gibi bazı yazım yanlışlarının temelinde Osmanlı Türkçesinin özelliklerinin kavranmamış olması vardır. Öğretim kademelerinde imlaya ve söyleyişe dönük uygulamalı ve kapsamlı bir öğretim yapılamadığından bugün bu tür kelimelerin imlasında ve söyleyişinde kargaşa yaşanmaktadır. Kargaşanın kaynağı dile ve kültüre karşı duyulan ilgisizliğin payı da inkâr edilemez.

\section{Alıntı Kelimelerin Türkçedeki Özellikleri ve Telaffuzdaki Durumları}

\section{Ünsüz Yumuşaması}

Türkçenin fonetik olarak temel özelliklerinden biri de ünsüz yumuşamasıdır. Ünsüz yumuşamasının Arapçadan girmiş bazı kelimelerde bozulduğu görülmektedir. Özellikle k ile biten kelimelerden öncesinde med varsa bu kelimeler yumuşamaz. Örnek; ittifakın, müttefikimiz, infakına, Irak'ın, emlaka, ahlaka, hukukun, evrakı, idrak.

Bir ünsüz, bir ünlü ve iki ünsüzden oluşan yabancı kaynaklı tek heceli kelimelerin de bir bölümünün son sesi ünlü ile başlayan ek aldığında yumuşar. Harç, felç, ferç, burç, zevç, cenk, darp, harp, garp, gasp, celp, cezp, sülp, tart, bent, dert, fert, cilt örneklerinde olduğu gibi. Ünlü ile başlayan bir ek aldıklarında son sesteki ünsüzler yumuşar ve harcı, felci, ferci, burcu, zevci, cengi, darbı, harbi, garbı, gasbı, celbi, cezbi, sülbü, tardı, bendi, derdi, ferdi, nezdi, cildi örneklerinde olduğu gibi son sesleri özgün yapılarına döner. Özgün yapılarında son sesleri sert olan ve Türkçeye de bu sert ünsüzleriyle giren halk, gark, fark, zevk, terk, misk, dost, züht, rint, mest, mert, sert kelimelerinde ise ünlü alsa bile son seslerde yumuşama olmaz. İnşaat, kıraat, ifşaat, külliyat, tarikat, hissiyat, malumat, melekut, menfaat, mevzuat, muamelat, müfredat, mükafat, lügat, saat, edebiyat, sadakat, sıhhat, sürat, şefkat, şefaat, tabiat, tatbik, tazyik gibi kelimelerde de yumuşama olmaz.

Ünsüz yumuşamasının olmadığı durumlar, Türkçe kelimeler için de geçerli olabilir. Bir ünlü, bir ünsüz sesten oluşan ve Türkçe olan, tek heceli $a c ̧, i c ̧, ~ u ̈ c ̧, a k, e k, o k, i p$, et, it kelimeleri ünlü ile başlayan bir ek aldıklarında bunların son sesleri değişmezken, aynı yapıda olan uç, ünlü ile başlayan bir ek aldığında son ses ucu biçiminde $c$ sesine dönüşür.

Türkçe kelimelerin sonunda $b, c, d, g$ ünsüzleri bulunmaz. Yabancı dillerden alınan kelimelerdeki bu sesler Türkçeye uyarlanarak $p, c ̧, t, k$ şeklinde telaffuz edilir ve yazılır. Örnek; aded> adet, kitab>kitap; mirac>miraç, sened>senet, şehid>şehit, ayb>ayıp, celb>celp, harb>harp, mahcub> mahcup, mensub > mensup, harc> harç, ihtiyac>ihtiyaç, akd > akit, evlad> evlat, aheng> ahenk, deng> denk, reng> renk; hudut, nakit, rakip, tabip, takip, takrip, talip, tasvip, vaat, vacip, şahit, şehit, taaccüp, velut, tedip, tehyiç, tecrit, temcit, terkip, tertip, tahdit, taklit, takip, taksit, talip gibi. Bu tür 
kelimelerden sonra ünlü geldiğinde bunlar asıllarına dönerek yumuşama olur. Yabancı dillerden alınan, asılları yumuşak ünsüz olan bu kelimelerde yumuşamanın olmadığı kelime yoktur. Bu öyle bir kuraldır ki Türkçe bazı kelimeler ünsüz yumuşaması kuralını bozarken yabancı dillerden giren kelimeler aslı gibi kullanılır. Örnek; Turgut - Turgut'a; Korkut- Korkut'un kelimeleri t ile telaffuz edilirken Samet, Ahmet, Mehmet (Muhammet) - Samet'i, Ahmet'in, Mehmet'e şeklinde yazılıp Samedi, Ahmedin, Mehmede biçiminde telaffuz edilir.

Cumhuriyet, milliyet, ibadet, ibret, abdest, dikkat, sepet, adalet, samimiyet, davet, şehvet, şerait, taahhüt, vasat gibi kelimelerdeki son sesler asıllarında sert ünsüz olduğundan bunlarda yumuşama olmaz.

Türkçe söyleyişin önemli kurallarından biri de ulamadır. Ulama sebebiyle yazım ve söylenişin farklılıkları da ortaya çıkar. Özellikle ulama yapılırken ünsüz yumuşaması kuralı sadece söyleyiş için geçerlidir. Bu noktada Arapça ve Farsçadan alıntı kelimelerde yukarıda belirttiğimiz husus önem arz etmektedir. Asıllarında b, c, d ile biten kelimelerin söylenişinde ünsüz yumuşamasına riayet edilir. Örnek; sebep olmak, (yazılışı) sebebolmak (söylenişi); mahcup olmak (yazılışı) mahcubolmak (söyleniş); muhtaç olmak (yazııışı) muhtacolmak (söylenişi); itimat etmek (yazılışı) itimadetmek (söylenişi).

Yine ünsüz yumuşaması kuralında k'den önce $n$ sesi varsa $k$ sesi, ğ’ye değil g'ye dönüşür. Bunun sebebi de bu kelimelerin asıllarındaki g sesidir. Örnek; ahenk- ahengi, mihenk-mihengi, renkrengi.

Ünsüz yumuşamasının ne tür kelimelerde tam olarak uygulandığını net olarak tespit etmek mümkün değildir. Türkçe kelimelerde de kuralın uygulanmadığı pek çok örnek mevcuttur. (bk. Temizyürk vd. (2012), Barın (2007). Bu konuda önemli verilerden biri asıllarında yumuşak ünsüzlerin ünsüz yumuşamasına uğramasıdır. Fakat bu durum da her zaman geçerli değildir. Murat abi, Fuat usta kelimelerinde ulama yapılırken asıllarında d'li olan bu kelimelerin $t^{\prime} l i$ söylenmesi gerekir. Aslında ikilemlerin sebebi dildeki canlılığın zamanla söyleyişleri Türkçeleştirmesidir. Uzun söylenişlerin 40- 50 yı öncesine göre daha az yapılması da bunun göstergesidir. Dilin zamanla evrimini tamamlayarak bu söylenişleri Türkçeleştirmesi de muhtemeldir.

\section{Uzun Ünlü}

Uzun ünlülerin söylenişleri Türkçe açısından önem arz etmektedir. "Kökeni Türkçe olan kelimelerde uzun ünlü yoktur. Uzun ünlü, Arapça ve Farsçadan Türkçeye giren kelimelerde görülür." (Yazım Kılavuzu 2005:5)

"Bir dile başka dilden giren sözcükler önce o dilin ses dizgesinin süzgecinden geçerler ve girdikleri dilin sesletim düzenine olabildiğince uymaya çalışırlar. Bu durum, her dil için söz konusu olduğundan doğal sayılmaktadır. Ancak, yabancı dillerden aldığımız sözcüklerin ünlülerinin tamamını kısaltarak söylemeye kimi zaman farklı anlamda başka sözcüklerle karıştırılmasına neden olabilmektedir. Örneğin de bağlacı yerine kullanılan /dahi/ bağlacı kimi zaman /da:hi/ olarak sesletilmektedir. Oysa bu sözcüğün anlamı tamamen farklıdır. Bu durumda, sözcüklerin sesletiminde barındırdıkları ünlülerin uzun ya da kısa söylenişlerine dikkat etmek ayrı önem kazanmaktadır." (Ergenç, 1995:38)

Bahsi geçen dillerden Türkçeye girmiş her uzun ünlü uzun söylenmez. Pek çok uzun ünlü zaman içerisinde kısalmıştır ve dilin canlı bir mekanizma olduğu göz önünde tutulduğunda bu eğilimin devam ettiği de görülmektedir. Örnek; mektup, hiç, beyaz, tamam. Fakat pek çok kelimedeki uzunlukların devam ettiği de bir vakıadır. Hatta bazı kelimelerde uzatma yapılmadığında veya uzatmanın yeri değiştirildiğinde anlam kaymalarının olması da kaçınılmazdır. Örnek; dîvan ile divan; âciz ile acze düşmek, âdil adaletle hükmeden anlamındayken adîl Allah'ın bir sıfatı olup çok çok adil olan anlamındadır. Benzer anlam kaymaları şu kelimelerde de vardır. Kâdir-kadîr, âlim- alîm, hâkimhakîm, râhim- rahîm, varis-vâris, vâkıf-vakıf, âciz-aciz , kâtil-katl. 
Bazı sesler ise aslında uzun ünlü olup dilimizde kısa söylenmesine rağmen ünlü ile başlayan bir ek aldıklarında uzun söylenir. "Uzun ünlülü kapalı hecelerle biten kelimeler ünlüyle başlayan bir ek aldıklarında veya yardımcı fiillerle kullanıldıklarında, açık duruma dönüşen hecenin ünlüsündeki uzunluk, söyleyişte yeniden ortaya çıkar (Yazım Kılavuzu 2005: 6)". Örnek; tamam > tamâmen, hukuk $>$ hukûkun, esas > esâsen, ruh > rûhum, vicdan > vicdânen, tahrik > tahrîk olmak, teşkil > teşkîl etmek, hitap > hitâb etmek.

Uzun söylenişleri devam eden bazı kelimeler şunlardır: Adâlet, âni, âniden, âsi, âciz, âdet, âdil, âheste, âlim, âşık, âşikâr, bahâne, bâkiye, basîret, bîçare, bilâkis, câhil, câiz, câmi, câzibe, cenâze, cehâlet, celâl, cesâret, cinâyet, dâhi, dâhil, dâima, delîl, dakîka, deyyûs, destûr, diyânet, düstûr, edâ, efkâr, emâye, enâniyet, fâil, fâni, fânus, gâlip, gûya, güzîde, iâde, ibâdet, idâme, îcap, icâzet, ihânet, ihâle, ihânet, ihmâl, ikâmet, îkaz, imâmet, isâbet, iskân, istiklâl, hâiz, hâcet, hâfıza, hakîkat, hükûmet, hâla, hazîne, hikâye, kâbus, kâinat, kâide, kâse, kefâlet, lâcivert, liyâkat, mahâret, mâhir, mahmûr, mahsûl, mâil, malûlen, mânia, meccâl, mekân, mesîre, metânet, mevcût, mezâlim, millî, muhâbere, muhâfız, müzmîn, nâçiz, nâil, nâdide, nedâmet, nihâyet, numûne, nüfûz, pâbuç, pâyidar, perîşan, peydâ, rutûbet, rüzgâr, sâye, sirâyet, sükût, şûra, tâbi, takdîm, tâli, teâmül, tekâmül, tesâdüf, tezâhür, umûmî, usûl, üslûp, vâde, vahâmet, vekâlet, vekîl, vîrâne, vücût, yekûn, zarâfet, zâyi.

Uzun ünlülerin telaffuzu, zaman zaman anlam farklılığına uğradığı için önemlidir. Uzun söylenilen ünlüler, Osmanlı Türkçesinin bakiyeleri olarak dilimizde yer almaktadır. Artık Arapça ve Farsça dillerinden yeni kelimeler alınmamaktadır. Bu açıdan bakıldığında uzun söylenişlerin kavranması için Osmanlı Türkçesi bilgisine ihtiyaç vardır. Kabul edelim etmeyelim bu kelimeler dilimize girmiş ve pek çok kelime grubunda, deyim ve atasözünde yer almıştır. Bu yüzden söylenişlerinde kurala uymak zorunluluğu vardır. Ancak bu uzun söylenişler, dilin canlı bir varlık olduğu gerçeği de düşünüldüğünde kaybolma sürecine girmiştir.

\section{Düzeltme Iş̧areti}

Bir yazım kuralı olarak kullanılan düzeltme işaretinin kullanıldığı kelimeler, Arapça ve Farsçadan dilimize girmiş kelimelerdir. Son Yazım Kılavuzu'nda düzeltme işaretinin kullanılacağı üç yer vardır. Yazılışları bir anlamları ve söylenişleri farklı olan kelimeleri ayırt etmek; ince $\mathrm{g}$ ve $\mathrm{k}$ ünsüzlerinden sonra gelen a ünlüsünü belirtmek ve nispet i'sini belirtme durum eki ile iyelik eklerinden ayırmak için düzeltme işareti kullanılır. Bütün bu kullanımlarında düzeltme işaretinin kullanıldığı ses uzun söylenir. Örnek; millî, ilmî, resmî, askerî, hukukî, mekân, hikâye, dükkân, rüzgâr, karargâh, tezgâh, yadigâr, Kâzım, Hakkâri, Kâbe, aşikâr, Mikâil, pişekâr, garazkâr, gâvur, girizgâh, günahkâr, güzergâh, harekât, hükûmet, yekûn, mahkûm, inmalkâr, imkân, inkâr, iskân, kâfi, kâfir, kâğıt, kâhin, kâinat, kâkül, kâmil, kâtip, mekân, nikâh, rekât, rengârenk, riyakâr, sahtekâr, sanatkâr, sükûn, sükûnet, sükût, şikâyet, tamahkâr, talimgâh, tavizkâr, tezgâh, vekâlet, zekâ, zekât.

Anlam farklılığı olan kelimelerde de düzeltme işareti kullanılır. Örnek; adem 'yokluk'- âdem 'insan'; adet 'sayı' - âdet 'gelenek';âmin 'dua sözü, amin 'kimya terimi'; ama 'fakat' âmâ 'gözleri görmeyen', aşık âşık;ayan 'belli açık' âyan 'ileri gelenler', ala 'karışık renkli'- âlâ 'yüce, yücelik'; bala 'çocuk'- Bâlâ 'Ankara'nın ilçesi'; batın 'karın'- bâtın 'iç, dahil'; dam 'çatı'- dâm 'tuzak'; dar 'ensiz'- dâr 'kapı'; duş 'banyo'- dûş 'omuz'; nar 'meyve'- nâr 'cehennem, ateş'- sal 'su taşııı' - sâl 'yıl'; varis 'hastalık' - vâris 'mirasçı olan'- yar 'uçurum'- yâr 'sevgili'; yad 'yabancı'-yâd 'anma'.

Telaffuz bakımından düzeltme işaretinin kullanıldığı kelimelerin durumu önemlidir. Öncelikle düzeltme işaretinin kullanıldığı kelimelerin anlam karışıklıklarının giderilmesi için uzun söylenmesi gerekir. Ayrıca ince söylenen $g$ ve $k^{\prime}$ den sonra gelen ünlülerin de ince söylenmemesi, Türkçede yapılan önemli telaffuz bozukluklarındandır. Yukarıdaki örneklerde verilen kelimelerin ince söylenmesi de gerekir. Bu kelimeler incelendiğinde Arapça ve Farsçada kef ile yazıldığı görülmektedir. Daha önceki imla kılavuzlarında ince söylenen l'den sonra gelen a'ların üzerinde düzeltme işareti vardı. TDK'nin yayımladığı son kılavuzda bu işaret kaldırıldığından yazımda gösterilmez. Fakat telaffuzda bunların da ince söylenmesi gerekir. helal, celal gibi. 


\section{Ünlü Düşmesi}

Arapçadan dilimize girmiş iki heceli ve ikinci hecesi dar olan isimlerde kelimeden sonra bir ünlü geldiğinde ikinci hecedeki dar ünlü düşer. Fikir> fikrin, şükür>şükrünü, akıl> aklını, asıl > aslına. Fuhuş, gönül, gusül, hacim, haciz, hapis, hatim, kabız, katil, kayıt, keşif, keyif, lütuf, meyil, nakit, nakil, nakış, nehir, nesil, nezir, rehin, remiz, resim, sabır, seyir, şahıs, şehir, şekil, şükür, ufuk, uzuv, vahiy, vakit, vasıf, vezin, zehir, zihin, zikir.

Bu tip kelimeler, yardımcı fiil alıp birleşik fiil oluşturursa bitişik yazılır ve tek kelime şeklinde telaffuz edilir. Fethetmek, sabretmek, şükretmek, hükmetmek, nakletmek.

Eğer birinci hecedeki ünlü veya ikinci hecedeki dar ünlü uzun ise burada ünlü düşmesi olmaz ve uzun söyleyiş devam eder. Rezilin biri, hukukun, herife, dâhilinde, haricinde, sükûta, huzûrunda, vekîlin, kusûru. Galip, gurur, gurup, güruh, habip, hafif, latif, lüzum, mahkum, mürur, nüfuz, nüfus, nüzul, rakip, sahil, sahip, sakin, sebil, sefil, sefir, şahit, şerik, , şümul, tabip, tabir, umum, usul, ümit, , vahim, vücut, zabit, zalim, zarif, zemin.

İsmi meful olup meful kalıbıyla yapılan kelimelerde uzunluk olduğundan düşme olmaz. Mahkum, merhum, mahsul, mahzun, mahmur, mağrur.

Tefil kalıbıyla yapılan kelimelerde de düşme olmaz. Tafsil, tahsil, tağyir, tahkim, tahkik, tahlil, tahmin, tahrif, tahsis, takdim, takdir, takip, taksim, talim, talip, tamir, tanzim, tarif, tashih, tasnif, tasvir, tasvip, tatbik, tatmin, taviz, tayin, tazyik, tebdil, tebrik, tebliğ, teçhiz, tedbir, tedhiş, tedris, tedvir, teftiş, tehdit, teklif, tekmil, telmih, tembih, temsil.

Türkçe kelimelerde de ikinci hecesi dar olan iki heceli organ isimlerinde ve bazı fiillerde ünlü düşmesi vardır. Ünlü düşmesi hem yazım hem de telaffuzda geçerli bir kuraldır. Özellikle birleşik fiil oluşturan kelimelerde söyleniş önemlidir. Hükmetmek, şükretmek gibi kelimeler, birleşik telaffuz edilmezse düşmenin olmaması gerekir. Ayrıca Türkçe söyleyişte kelimeler arasında çok kısa da olsa bir durak ve her kelimede bir vurgu vardır. Hâlbuki bu tür birleşik kelimeler duraksız ve tek vurgulu söylenmelidir.

\section{Ünlü Uyumu Kuralları}

Türkçeye girmiş bazı kelimeler, değişikler yapılarak daha doğrusu Türkçe kurallara uydurularak kullanılmaktadır. Özellikle büyük ve küçük ünlü uyumu kuralları, bazı kelimelerde değişiklik meydana getirterek kelimelerin dilimize girmesine yol açmıştır. Örnek; müdir> müdür 'idare eden'; divar > duvar; faide > fayda; zaif > zayıf; sahife> sayfa; seray> saray; serhoş > sarhoş, çünki> çünkü; guzide> güzide; gûşe> köşe; tahte> tahta; gofte> güfte; servan > serüven.

Sonu $\mathrm{I}, \mathrm{t}$ ve $\mathrm{k}$ ile biten kelimelerden önce uzatma varsa bu kelimelerin son hecesi kalın dahi olsa gelen ek ince olur. Saatin, firkatin, sadakatin, hakikati, kanaatimiz, dikkatine, idraki, istikbalde, idraksiz, itaatsiz, helakimiz, arzuhâlci, dikkatini, nasihat, ihtimal, celal, hilal, mahsulü, hayal, hal, helal, ihlal, ihmal, ihtilal, ihtimal, inzal, intihal, ishal, kanaati, mahsul, mecal, lügat, misal, nüzul, sıhhat, şimal, şümul, timsal, usul, vebal, Bu kuralı bozan söylenişler de vardır. Emlakçı, edebiyatın, sanata, ahlakı, inşaat, evrak, hayat, itikatlı, itimatlı.

Meful kalıbında olan ve sonu I ile biten kelimelerden sonra ince ünlü gelir. Malulen, mahsulü, mamulleri, mesuliyet.

Kalın sesten sonra ince söyleyişin olduğu durumlar için bir kural belirlemek zordur. Fakat ince söylenen kelimelerde dikkat çeken husus, bunların son ünlülerinin asıllarında uzun olmalarıdır. Bu, tek başına belirleyici olmamakla beraber önemli bir ayrıntıdır. Hatta aynı kelimenin değişik kullanımlarında ince ve kalın şekillerine rastlamak da mümkündür. Örnek; malı, malı, malda kelimesinde kalın söyleyiş hâkimken, maliyet, maliye kelimelerinde aslına uygun olarak ince söylenmelidir. 
Arapça -iyet ekiyle yapılan türemiş kelimelerde ekin kalın şekli kullanılmaz. Örnek; insaniyet, mahkumiyet. -en eki de büyük ünlü uyumunu bozmaktadır. Örnek; aslen, tamamen, kısmen, atfen, aynen.

Bağlama edatı olarak kullanılan ki, Farsçadan dilimize girmiş bir ektir. Türkçemizde kullanıldığı şekliyle bitişik yazıldığında büyük ve küçük ünlü uyumlarını bozmaktadır. Ekin Türkçede ek olarak iki kullanımı vardır. Ki ve kü. ince-yuvarlak ünlülerden sonra kü’lü kullanımı varken diğer bütün kullanımlarında ki şeklinde yazııı söylenmektedir. Örnek; çünkü, (Bazı söyleyişlerde çünkinin devam ettiği de görülmektedir.) bugünkü, dünkü, öbürkü, öteki, onunki, halbuki, sanki, okuldaki, sabahki. Bağlama edatı olarak kullanıldı̆̆ında ki olarak tek şekillidir. Okuyordum ki, görmüş ki, gelecek ki, diyor ki.

\section{Ünsüzlerin Özellikleri}

Türkçe seslerini korumada muhafazakâr bir yapıya sahiptir. Yabancı dillerden Türkçemize girmiş kelimelerde Türkçede olmayan sesler varsa bu sesler olduğu gibi alınmıştır. Örneğin; jandarma, jale, ambalaj, fakat, fen, farz, ferah, fert, feraset, kelimelerindeki $f$ ve $j$ sesleri Türkçe kelimelerde yansıma kelimeler dışında kullanılmaz. Fakat seslerin karşııkları varsa Türkçedeki şekilleri kullanılır. Örneğin z ve s sesleri Türkçede olduğundan peltek z ve peltek s sesleri alıntı kelimelerde dahi olsa kullanılamaz. Eser, zevk, kelimelerindeki z ve s sesleri peltektir. Dad sesi de Türkçede $d$ ve $z$ seslerine dönüşerek söylenmektedir.

Türkçenin sesleri kolay telaffuz edilen seslerdir. Türkçenin ünlü ve ünsüz bütün sesleri ağız bölgesinde meydana gelir. En gerideki ses, gırtlak ünsüzü olan h sesidir. Bu sesten daha geride özellikle boğazdan çıkan sesimiz yoktur (Temizyürek vd. 2007: 181). Oysa özellikle Arapça $h$, ayn gibi boğaz ünsüzlerine sahip bir dildir. Bu sesler standart Türkçe telaffuzda bulunmayan seslerdir. Hırıltılı h ünsüzü ağızlarda kullanılmasına karşın standart Türkçede kullanılmaz. Bu yüzden Arapça asıllı kelimelerdeki bu sesler Türkçe söyleyişe göre telaffuz edilmelidir. Halk, 'ayıp,

Ünsüzlerle ilgili fonetik değişiklerin meydana gelen değişmelere de şu örnekler verilebilir. Örnek; hoş-ab> hoşaf; rencber> rençber; cift> çift; sadrenc> satranç; çar-su > çarşı; piş-kes> peşkeş; penç-şenbih> Perşembe; çehar şenbih> Çarşamba; dest-gah> tezgah; ab-ı dest> abdest.

Hemze ve ayın Arap dilindeki konsonantlardandır. Türkçede bu sesler yoktur. Arapçada hemze ve ayınlı bazı kelimeler Türkçede kesme şeklinde gösterilmektedir. Bu kullanım yüzünden bu kelimelerin telaffuzu da Arap diline göre yapılmaktadır. Bu seslendirmenin son zamanlarda kaybolduğu görülmektedir. Mes'ele> mesele; mes'ul> mesul; mes'ut> mesut; rü'ya> rüya; san'at> sanat; mel'un> melun, la'net> lanet kullanımlarından ikinci şekilleri doğrudur. Sadece Kur'an-ı Kerim derken terim olduğundan kesmeli şekilde telaffuz edilmelidir ancak bunun da zaman içinde kaybolacaktır. Yine bu seslerin oluşturduğu birleşik fiillerde ses türemesi olduğundan bunların bitişik yazılması ve tek kelime gibi telaffuzu doğrudur. Defetmek, defolmak, cemetmek, menetmek, menolmak, tabetmek, vazeylemek, vadetmek, .

Kelime içinde $b$ ile başlayan hecelerden önce $n$ ünsüzü varsa $n$, m'ye dönüşür. Bu bazı alıntı kelimelerde değişikliğe yol açar. Örnek; çehar şenbih> çarşamba; penç şenbih > perşembe; can baz > cambaz.

Türkçede iki ünlü yan yana kullanılmaz. Türkçede kök ve ek birleşiminde iki ünlünün bir arada kullanılması için kaynaştırma harfleri kullanılır. Bu durum bazı alıntı kelimeler için de geçerlidir. Örnek; camii > camisi, sanai > sanayi, fiat > fiyat, mai> mavi.

\section{ikiz Ünsüz}

Arapçadan dilimize girmiş ve sonunda ikiz ünsüz (şedde) bulunan kelimelerin yalın durumunda ünsüzlerden biri düşer. Örnek; fenn $>$ fen, hiss $>$ his, hacc $>h a c$, zann $>$ zan, redd $>$ ret hakk> hak, hall> hal.had, hak, hat, şek, şer, Rab, tıp. Bu kelimelere ünlüyle başlayan bir ek geldiğinde ünsüzler tekrar ikizleşir. Örnek; fennin, hissine, zannımca, reddine, halline. Bu tür kelimeler, yardımcı 
fiille birleşerek birleşik fiil meydana getirdiğinde bitişik yazılır ve bir kelime gibi telaffuz edilir. Halletmek, hissetmek, zannetmek, halletmek.

Türkçe kelimelerde istisnalar dışında kelime kökünde ikiz ünsüz (şedde) bulunmaz. Yabancı dillerden Türkçemize girmiş ikiz ünsüzlerin yazımında ve telaffuzunda Türkçenin bu kuralına uyulduğu görülerek bu ünsüzler bazen tek sese dönüşür. Arapçada şeddeli kullanılan y'leri Türkçede tek sese dönüşür. Milliyyet> milliyet, hürriyyet> hürriyet, belediyye> belediye, mülkiyye> mülkiye, adliyye >adliye, rantiyye >rantiye, hammam > hamam; hammal $>$ hamal, kerre $>$ kere, çille> çile, Hatta bu kural Batı dillerinden giren kelimelerde de görülür. Entelektüel, alerji

Aynı yapıda olan ve aslında son seste ikiz ünsüz bulunduran "ilâç" anlamındaki Arapça hap kelimesinde böyle bir durum yoktur. Hapı yuttum örneğinde ikiz ünlü kullanımı son seste söz konusu olmaz.

\section{Ek ve Kelimeler}

Türkçe sondan eklemeli bir dildir. Alıntı kelimelerde ise ön eklerin kullanıldığı görülür. Özellikle kelimeyi olumsuzlaştıran bazı eklerin Arapça ve Farsçadan alıntılandığı görülmektedir. Bî, na, la, gayr ekleri kelimenin anlamını olumsuz yapar. Bî-baht, bî-ilaç, natamam, lakayt, gayrımemnun. Olumsuzluk yapan ön eklerin söylenişleri uzundur. Ayrıca bu kelimeler, basit kelimeler gibi tek vurgulu söylenmelidir. Gayr ile yapılan kelimeler, son kılavuzda bitişik yazıımıştır. Bu söyleyişi de etkileyecek bir uygulamadır. Herhalde diğer olumsuzluk yapılarıyla da benzerlik oluşturularak söyleyişte de bir standart oluşturulmaya çalışılmaktadır. Fakat bu standardın oluşması zaman alacaktır. Bugüne kadar bu yapıların ayrı yazılıp duraklı ve iki vurgulu söylenmesi yaygındı. Ancak Arapça harfitarifle yapılan tamlamalarda bu süreç tamamlanmış ve bu kelimelerin tek kelime gibi birleşik yazııması ve tek kelime şeklinde telaffuzu yaygınlaşmıştır. Aynı durum, Farsça tamlama i'siyle kurulan diğer tamlamalar için de yaygınlaşabilir.

Benzer söyleyiş diğer birleşik kelimeler için de geçerlidir. Birleşik kelimeler, duraksız ve tek vurgulu söylenmelidir. Suikast, suizan, suistimal, misafirhane, hastane,

Hane kelimesiyle yapılan birleşik kelimelerde $\mathrm{h}$ sesinin aşınarak söylenmediği durumlar vardır. Bu durum, kimi zaman yazımda da sorunlara sebep olmaktadır. Gerek konuşma gerekse yazı dilinde hane kelimesinden önceki ses, a sesi ise 'ha' hecesi düşer. Hasta hane> hastane, posta hane> postane, ecza hane> eczane. Şifahane bu kuralın dışındadır.

Olumsuzluk eki bî ile harfi cer olan bi, her ikisi de ön ek olarak kullanılmaktadır. Fakat olumsuzluk eki uzun söylenirken harficer olan bi kısa söylenmelidir. Bunları ayırt etmek için anlamlarına bakılabilir. Ayrıca harficer olan bi Osmanlı Türkçesinde daha çok harfitarifle kullanılmaktadır. Örnek; bilumum, bilfiil gibi.

\section{Sonuç}

Arap ve Fars dillerinden Osmanlı Türkçesi vasıtasıyla dilimize girmiş önemli miktarda kelime vardır. Bu dillerden kelime girişi durmuş olmasına karşın mevcut kelimelerin nasıl yazıııp söyleneceği de tartışılmaktadır. Türkçemizde olmayan bazı söylenişlerin bu dillerden dilimize girmiş olması tartışmanın asıl sebebidir. Canlı bir varlık olan dil, yabancı kelimeleri de zamanla kendi kurallarına benzetse de bu dillerin söyleyiş özelliklerinin hâlâ var olduğu gerçeği inkâr edilemez. Bu yüzden telaffuz standardının oluşması için bu kelimelerin özelliklerini de bilmek gerekir.

\section{Kaynakça}

Akçay, C. (2001). Hanna Mine'nin romanlarındaki Türkçe kelimeler ve çeviri öğeleri. Nüsha. Sayı:3, Güz 2001. Aytaç, B. (1994). Arap lehçelerindeki Türkçe kelimeler. İstanbul: TDAV Yay.

Barın, E. ve Demir, C. (2007). Türk Dil Bilgisi-1. Ankara: Öncü Kitap.

Duman, M.( 2004). Modern Türkiye Türkçesinde yazı ve söyleyiş ilişkisi. Türk Dili, Sayı: 625. Ocak 2004.

Ergenç, i. (1995). Konuşma dili ve Türkçenin söyleyiş sözlüğü. Ankara: Simurg Yay.

Korkmaz, Z. (2003). Türkiye Türkçesinde yazı diline girmiş günlük yaşamla ilgili alıntı sözler ve ekler. Türk Dili, S. 620 
Özçelik, S. (2002). Türkçedeki Farsça kelimelerde görülen ses olayları. Türk Dili, S.612, Aralık 2002.

Sakaoğlu, S. (2005). Türkçenin güncel sorunları. Türk Dili, S. 646, Ekim 2005.

Temizyürek, F., Erdem, i. ve Temizkan, M. (2012). Konuşma Eğitimi. Ankara:Pegem Akademi

Usta, H. İ. (1990). Yabancılaşmanın söz dizimindeki görünümleri. Türk Dili, S. 463. Temmuz 1990. Yazım Kılavuzu (2005). 24. Baskı. Ankara: TDK Yay.

Zülfikar, H. (2002a). Doğru yazalım doğru konuşalım. Türk Dili, Sayı:604, Nisan 2002.

Zülfikar, H. (2002b). Doğru yazalım doğru konuşalım. Türk Dili, Sayı:602, Şubat 2002. 